\title{
Cystoderma castellanum, a new species from Spain
}

\author{
Blanco-Dios JB $\mathbf{~}^{1}$ \\ ${ }^{1}$ Centro de Formación e Experimentación Agroforestal de Lourizán. Consellería de Medio Rural. Xunta de Galicia. \\ P.O. Box 127. 36080 Pontevedra,Spain
}

Blanco-Dios JB 2014 - Cystoderma castellanum, a new species from Spain. Mycosphere 5(5), 688-691, Doi 10.5943/mycosphere/5/5/10

\begin{abstract}
Cystoderma castellanum is described as a new species from Castilla y León ( $\mathrm{N}$ of Iberian Peninsula). This new species is characterized by amyloid spores, cheilocystidia flexuous, utriform or lecithiform and $\mathrm{KOH}$ reaction brown or black.
\end{abstract}

Key words - Basidiomycota - Agaricales - Agaricaceae - Cystoderma - Spain - taxonomy.

\section{Introduction}

The species of the genus Cystoderma Fayod (Agaricaceae) were separated in two distinct genera, Cystoderma s. str. and Cystodermella by Harmaja (2002), in consideration of the amyloidity of the basidiospores and previously unused differences or tendencies present in the genus, such as 'harpoon' cystidia, arthrospores in fruit body and/or mycelium culture, liability to Squamanita, bryophily, nuclear DNA content and the results of phylogenetic analysis (Capelari \& Asai 2009). The separation Cystodermella from Cystoderma was well-supported in LSU and ITS rDNA data phylogenetic analyses. Spore wall amyloidity is the main character (but no definite) applied for distinguishing the genera Cystoderma and Cystodermella: the majority of species from genus Cystoderma are characterized by weakly to strongly amyloid basidiospores, but $C$. aureum (Matt.) Kühner \& Romagn. and $C$. japonicum Thoen \& Hongo having inamyloid basidiospores; moreover, the taxa from genus Cystodermella possess inamyloid basidiospores and the presence of cystidia is distinctive to few species (Saar 2012).

Cystoderma is a genus with a world-wide distribution and, according to Kirk et al. (2008), contains approximately 35 species, but the majority of taxa are described from temperate regions. Recently, a species of this genus not matching any other described taxa was found in pine (Pinus halepensis Mill., P. pinaster Aiton, P. pinea L.) forests in Castilla y León, Spain. Due to its unique combination of morphological characteristics, Cystoderma castellanum is proposed as a new species in this contribution.

\section{Materials \& Methods}

The specimens were collected, documented and preserved using standard methods. Morphological descriptions are based on the study of the fresh material. Microscopic observations were recorded on fresh or dried material with standard methods, using sections mounted in a solution of $1 \%$ Congo Red in water after a short pre-treatment in a 5\% potassium hydroxide 
solution, in Melzer`s reagent or in $\mathrm{NH}_{4} \mathrm{OH}$. Basidiospores measurements (length, width, Q (quotient length/width) were taken for 100 basidiospores. Microscopic structures were drawn with help of a drawing tube. The collected material has been deposited in the mycological herbarium LOU-Fungi (Centro de Investigación Forestal de Lourizán, Pontevedra, Spain).

\section{Results}

Cystoderma castellanum Blanco-Dios, sp. nov.

Figs. 1-6 MycoBank: MB 808222

Etymology - castellanum, from the community of Castilla y León (Spain).

Pileus 19-37.5 mm latus, primo hemisphaericus, deinde applanato-convexus, superficies granuloso-squamulosus, brunneo-cinnamomeus, brunneus vel nigrescens in KOH. Lamellae albidae-cremeae, adnexae. Stipes 18-27 × 3-10.5 mm,brunneo-purpureus, granuloso-squamulosus supra annulus et furfuraceus infra annulus fugax. Sporae (3.5-) 4-5 (-5.5) $\times(2-) 2.5-3(-3.5) \mu \mathrm{m}$, $Q=1.2-1.8$ (2), amyloideae, ab late ellipsoideae ad oblongae. Basidia 14-22 × 4.5-8 $\mu \mathrm{m}$, tetrasporigera, clavata vel anguste clavata. Cheilocystidia 13.5-18 $\times 3-6 \mu m$, sparsa, flexuosa, utriformia vel lecithiformia. Pileipellis catenis sphaerocystarum composita, arthrosporae desunt. Hyphae fibulatae. Inter muscus in pinus nemoris crescens.

Holotype - SPAIN. Valladolid: Bercero, $710 \mathrm{~m}$, under $P$. halepensis and $P$. pinea, among mosses, 30 December 2013, J.B. Blanco-Dios (LOU-Fungi 19663).

Pileus 19-37.5 mm diam., ovoid to convex when young, broadly campanulate to applanate when well developed, margin at first incurved slightly and appendiculate with the veil remnants, surface dry, not hygrophanous and granular-furfuraceous or covered with small conic granulose scales, colour variable, sometimes evenly coloured but often darker on the disc, russet to tawny and the margin paler, usually dull reddish cinnamon when dried. $\mathrm{KOH}$ reaction brown or black. Lamellae adnexed and rounded next to the stipe or adnate with a decurrent tooth, moderately crowded, broad and at times somewhat ventricose, white to pale yellowish, with lamellulae of different lengths, with entire or irregular and concolorous lamellar edge. Stipe 18-27 × 3-10.5 mm, subcylindrical or slightly subbulbous at the base, usually rather short in relation to the width of the pileus, solid to hollow, surface granulose-scaly to the evanescent pallid fibrillose apical annular zone or merely forfuraceous, brown-purplish above the annular zone, brown-ochre below. Context whitish or flushed pale rufous, thin. Odor and taste among aniseed, herbaceous and like rubber. White mycelium at the base. Spore print whitish.

Basidiospores (3.5-) 4-5 (-5.5) × (2-) 2.5-3 (-3.5) $\mu \mathrm{m}, \mathrm{Q}=1.2-1.8(2)(\mathrm{n}=100)$, broadly ellipsoid to oblong, smooth, thin-walled, hyaline, amyloid, without germ pore. Basidia 14-22 $\times$ 4.5-8 $\mu \mathrm{m}$, clavate to narrowly clavate, hyaline, inamyloid, thin-walled, 4-spored, sterigmata up to 7 $\mu \mathrm{m}$ long. Basidioles present, similar to basidia. Cheilocystidia 13.5-18 $\times 3-6 \mu \mathrm{m}$, inamyloid, flexuous, utriform or lecithiform, scattered. Pleurocystidia absent. Pileipellis formed by chains (sometimes forming short chains) of sphaerocysts, 11.5-33.5 × 7.5-28 $\mu \mathrm{m}$, preponderantly subglobose or ovate, sometimes reniform, pyriform, clavate, sphaeropedunculate or cylindricalconical, faintly rugulose, with thin to thick wall, smooth, vacuolar content, hyaline, subhyaline, ochre to brown in $\mathrm{H}_{2} \mathrm{O}$, subhyaline, ochre to brown in $\mathrm{NH}_{4} \mathrm{OH}$, not darkening in $\mathrm{KOH}$, arthrospores absent. Stipitipellis composed of parallel (at times interwoven) and vertically oriented hyphae 1-7 $\mu \mathrm{m}$ broad, cylindric, subcylindric to slightly inflated, sometimes constricted, with sphaerocysts 9$24.5 \times 5.5-18.5 \mu \mathrm{m}$, sparse, similar to those forming the pileipellis but preponderantly subglobose or ovate, sometimes reniform or cylindrical-conical. Clamp connections abundant.

Habitat - in pine (Pinus halepensis, $P$. pinaster, $P$. pinea) forests, among mosses.

Known distribution - up to now known only from two localities in Avila and Valladolid Provinces (Spain).

Material examined - SPAIN. Castilla y León: Valladolid: Bercero, $710 \mathrm{~m}$, under Pinus halepensis and P. pinea, among mosses, 30 December 2013, J.B. Blanco-Dios, LOU-Fungi 19663(holotype). Ávila: Arévalo, 820 m, under Pinus pinaster in sandy soil, among mosses, 2 

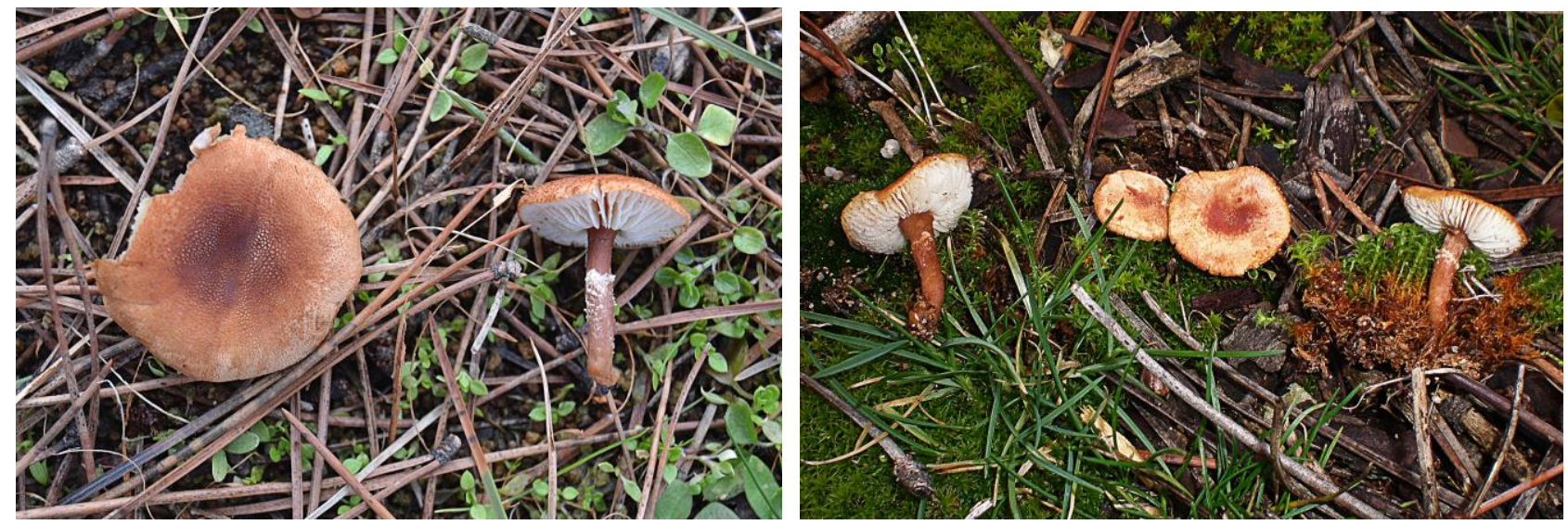

Figs 1-2 - Cystoderma castellanum. LOU-Fungi 19663 (Holotype) (left). LOU-Fungi 19662 (right).
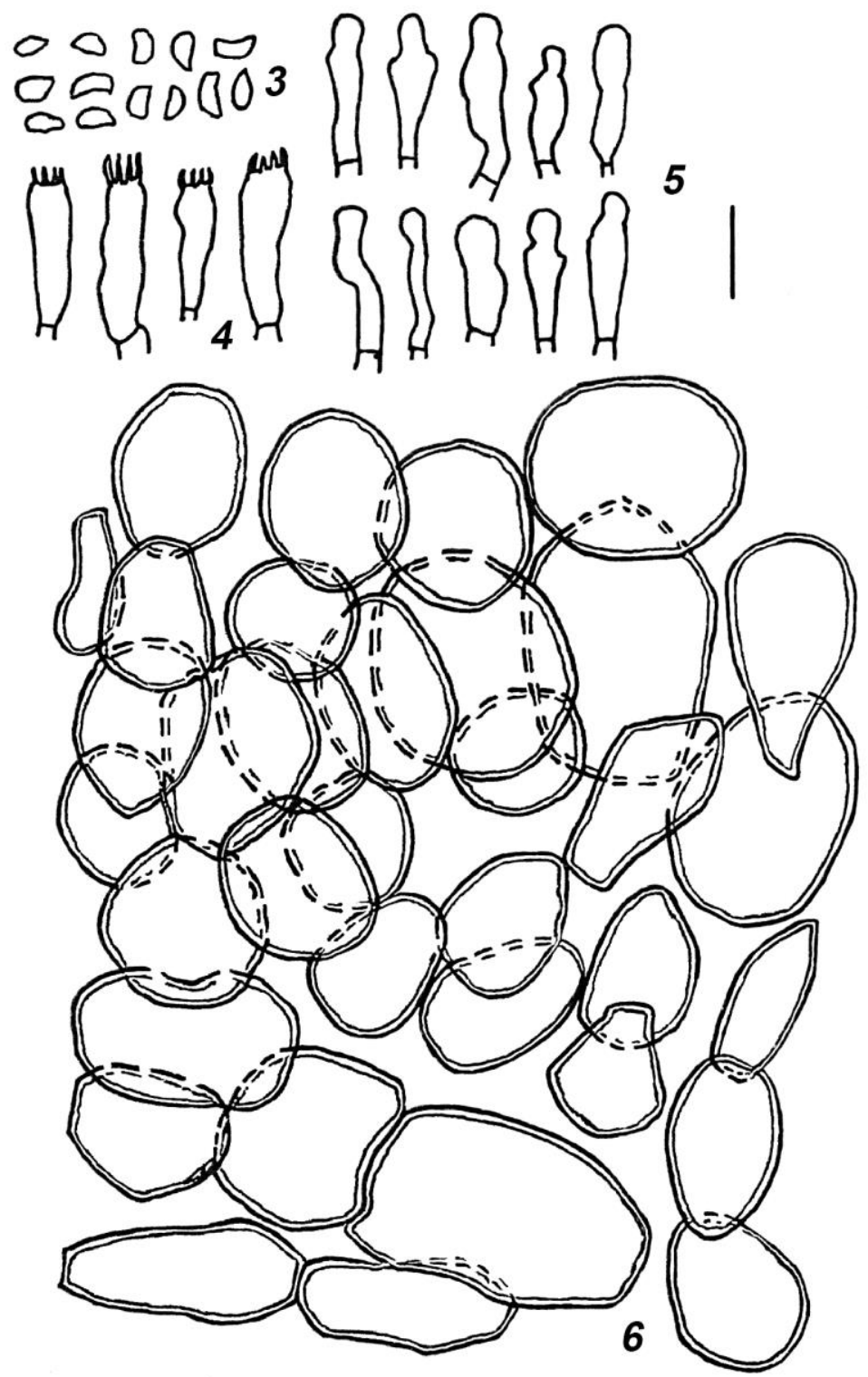

Figs 3-6-Cystoderma castellanum (holotype, LOU-Fungi 19663). 3. Basidiospores. 4. Basidia. 5. Cheilocystidia. 6. Sphaerocysts from pileipellis. Scale bar $=10 \mu \mathrm{m}$. 
January 2011, J.B. Blanco-Dios, LOU-Fungi 19662.

\section{Discussion}

Cystoderma castellanum is clearly accommodated in the genus Cystoderma because it has amyloid basidiospores (Harmaja 2002). This new species is easily characterized by present amyloid spores, (3.5-) 4-5 (-5.5) × (2-) 2.5-3 (3.5) $\mu \mathrm{m}, \mathrm{Q}=1.2-1.8$ (2), cheilocystidia flexuous, utriform or lecithiform and $\mathrm{KOH}$ reaction brown to black.

Among the morphologically similar species, the closest taxa are extra-European: Cystoderma ferrugineum (Bres.) Pegler, African species native to Democratic Republic of the Congo (formerly Zaire), differs specially by the small pileus (4-5 $\mathrm{mm}$ diam.) absent of cystidia and habitat on marshy ground (Pegler 1966, Thoen 1969, Heinemann \& Thoen 1973a, 1973b). Cystoderma chocoanum Franco-Mol., known from Brazil and Colombia, differs in having larger basidiospores, lack of cystidia and habitat on decaying wood (Franco-Molano 1993; Capelari \& Asai 2009).

\section{Acknowledgements}

The author is grateful to Dr. Irja Saar for his comments. Helena Velayos are gratefully acknowledged for kindly sending relevant literature. Amancio Castro is gratefully acknowledged for providing technical assistance. We express the most sincere thanks to the Director and members of the Centro de Investigación Forestal de Lourizán (Consellería do Medio Rural e do Mar, Xunta de Galicia) for conserving the herbarium LOU-Fungi.

\section{References}

Capelari M, Asai T. 2009 - Cystoderma, Cystodermella and Ripartitella in Atlantic Forest, São Paulo State, Brazil. Hoehnea 36(2), 339-348.

Franco-Molano AE. 1993 - Studies on Cystoderma: a new species and a new combination. Mycologia 85 (4), 672-676.

Harmaja H. 2002 - Amylolepiota, Clavicybe and Cystodermella, new genera of the Agaricales. Karstenia 42, 39-48.

Heinemann P, Thoen D. 1973a - Flore illustrée des champignons d'Afrique centrale 2. Leucocoprineae p.p. (Agaricaceae), Cystoderma (Tricholomataceae). Ministère de l'agriculture, Jardin Botanique National de Belgique, Meise, 1-51.

Heinemann P, Thoen D. 1973b - Observation sur le genre Cystoderma. Bulletin Trimestriel de la Société Mycologique de France 89, 5-34.

Kirk PM, Cannon PF, Minter CW, Stalpers JA. 2008 - Ainsworth \& Bisby's Dictionary of the Fungi. 10 ed. CAB International, Wallingford.

Pegler DN. 1966 - Tropical African Agaricales. Persoonia 4 (2), 73-124.

Saar I. 2012 - The taxonomy and phylogeny of the genera Cystoderma and Cystodermella (Agaricales, Fungi). Dissertationes Biologicae Universitatis Tartuensis 210.Tartu University Press, Estonia.

Thoen D. 1969 - Le genre Cystoderma (Tricholomataceae) en Afrique centrale. Bulletin du Jardin Botanique National de Belgique 39, 183-190. 